\section{Physiology in Modern Medicine}

By Prof. J. J. R. Macleod, assisted in the present edition by Prof. Philip Bard, Prof. Edward P. Carter, Prof. J. M. D. Olmsted, J. M. Peterson, Prof. N. B. Taylor. Seventh edition. Pp. xxxii $+1154+7$ plates. (London: Henry Kimpton, 1935.) 36s. net.

WE are fortunate in acquiring a new edition of this standard book on physiology since it turned out to be the last work of Prof. Macleod. During his extensive investigations, he made substantial contribu. tions to the science of physiology especially on carbohydrates, while during his many years of teaching medical students in Great Britain and in Canada he established many friends in both continents. This explains the multiple authorship of the book and the guiding principles underlying its general design : Prof. Macleod here presents physiological principles on a strict physico-chemical basis. He has even gone further and has brought the phenomena of several diseased conditions to the same scientific basis.

It is this single purpose, which applies to the working of disabled as well as normal organs, which makes reading pleasant and ensures that the thousand pages are none too many. Some of the early chapters are expressly devoted to purely physical considerations, so that the reader can be sure of following the more applied sections of the book.

For the medical student who wants a scientific text-book of physiology and for the practitioner who wants to establish his everyday practice gained by experience on a scientific basis, this book will be found useful. It is one of the best books available which combines the modern science of physiology with the old art of medicine.

Factor Analysis in the Study of Personality

By John Clemans Flanagan. Pp. $x+103$. (Stanford University, Calif.: Stanford University Press; London: Oxford University Press, 1935.) 6s. net.

THIs monograph gives a clear account of the develop. ment of the statistical techniques that have been devised to analyse the multiple factors involved in tests and ratings, arid in particular in those that are employed in personality study.

Beginning with Spearman's two-factor theory, the adequacy of which to deal with the simple case of hierarchical correlations is admitted as "firmly established", the author points out that this theory is inadequate to deal with complex factor patterns, in respect of which the work of Kelley, Thurstone and Hotelling is examined. The aim of all such techniques is to discover the basic independent factors which enter into functional synthesis and appear as abilities. These factors are 'indicated' rather than defined by the statistical procedures; and it remains to construct mental tests which will emphasise the factors individually in such a manner as to allow of the determination of their nature.

Factor analysis is rapidly coming to the fore in psychological work; and this monograph will be studied with profit by those who wish for a concise introduction to it.

\section{Garden Science}

By Dr. John Grainger. Pp. ii +265 . (London : University of London Press, Ltd., 1935.) 4s. 6d. net.

IN this small volume a considerable amount of information concerning the fundamental principles underlying the practice of horticulture is compressed. It consists of eight chapters, the first three of which deal with physiology as concerned especially with the raising and growing of plants. The fourth chapter, dealing with vegetative propagation, grafting, pruning and the like, is of value to gardeners since it contains scientific information on subjects often ignored in text-books. The last three chapters deal with diseases (fungus and virus) and insect pests : they cover \& wider range than might be expected in so small a volume (though T.S.W. virus is not mentioned), and many readers might prefer a fuller treatment of fewer subjects.

The section dealing with the flowers and the exposition of Mendelism is good, but the differentiation of the mechanisms which insure cross-pollination and those which prevent self-pollination is not very clearly defined. In the plant disease chapters the long. abandoned name Synchitrium [sic] solani is employed instead of Synchytrium endobioticum now in general use, whilst an error has obviously crept into Fig. 32. The book will be decidedly useful for purposes of horticultural training in schools and colleges.

\section{Tissue Culture:}

the Growth and Differentiation of Normal Tissues in Artificial Media. By E. N. Willmer. (Methuen's Monographs on Biological Subjects.) Pp. viii $+126+2$ plates. (London: Methuen and Co., Ltd., 1935.) 4s. net.

THIs brief account of the technique and results of the culture of tissues in vitro is to be commended to senior students of the biological subjects, as it presents the state of knowledge both of the growth and differentiation of the cell as well as a clear description of the role of the nutrient medium. The physiology of unorganised growth in epithelia and connective tissue is discussed with the same clarity as the organisation of embryonic tissues grown in cultures. The author is to be complimented on the avoidance of technical terms. A glossary, comprehensible even to the layman, is included.

\section{Tropical Planting and Gardening:}

with Special Reference to Ceylon. By H. F. Macmillan. Fourth edition. Pp. $x+560$. (London : Macmillan and Co., Ltd., 1935.) 25s, net.

IN Ceylon, cultivation, whether for profit or pleasure, is conducted under very varied conditions due to the great range of both altitude and rainfall. A com. prehensive account of what is possible there is thus of great utility to residents in many parts of the tropics and sub-tropics. This work, now in its fourth edition, thoroughly revised and enlarged is, even more than its predecessors, an indispensable book of reference for all planters and gardeners in tropical countries, its value being enhanced by its wealth of illustrations and very full index. 